\title{
THE QUALITY IMPROVEMENT IN ICT APPLICATION FOR INDONESIAN LANGUAGE LEARNING THROUGH LESSON STUDY FOR LEARNING COMMUNITY
}

\author{
Restu Bias Primandhika ${ }^{1}$, Dida Firmansyah ${ }^{2}$ \\ 12 IKIP Siliwangi, Jl. Terusan Jendral Sudirman, Cimahi, Indonesia \\ ${ }^{1}$ restu@ikipsiliwangi.ac.id, ${ }^{2}$ dida-firmansyah@ikipsiliwangi.ac.id
}

Received: Desember 15, 2017; Accepted: January 5, 2018

\begin{abstract}
This article discusses the practise of lesson study conducted in the higher level of education in order to design a better lesson in ICT Application for Indonesian Language Learning. This study is a descriptive research which has done in one class of Indonesian Language Education Study Programme involving two role-model teachers with three observers as a team. The team was involved in designing, observing and evaluating each lesson that is conducted in two cycles for two months. The lesson materials are the use of Microsoft Office for editorial and journalism purpose as the study programme speciality, such as 1) the basic skills of proof-reading tools in Word 2) write a mind-mapping style notes and journalist organisation in OneNote 3) typography, writing style and adaptation for article publishing. The result shows that the practise of lesson study improves the learning quality both for teachers and student activities, especially in collaboration, communication, critical thinking ability, and creativity.
\end{abstract}

Keywords: Lesson Study, ICT, Language Learning, Microsoft Office

\begin{abstract}
Abstrak
Penelitian ini membahas mengenai pelaksanaan lesson study di jenjang perkuliahan dengan tujuan merancang pembelajaran yang lebih baik untuk Aplikasi TIK dalam Pembelajaran Bahasa Indonesia. Penelitian ini merupakan penelitian eksploratif yang dilaksanakan di salah satu kelas di Program Studi Pendidikan Bahasa Indonesia; dengan melibatkan dua dosen model dan tiga pengamat dalam sebuah tim. Tim terlibat dalam perancangan, pengamatan dan penilaian setiap pertemuan yang dilaksanakan dalam dua siklus selama dua bulan. Materi yang diberikan adalah penggunaan Microsoft Office untuk keperluan penyuntingan dan jurnalistik sebagai kekhasan program study, di antaranya 1) dasar-dasar penyuntingan dalam Word 2) Penulisan catatan peta konsep dan pengelolaan jurnalis dalam OneNote 3) tipografi, gaya penulisan dan adaptasi untuk penerbitan artikel. Hasil menunjukkan bahwa pelaksanaan lesson study dapat meningkatkan kualitas dosen maupun aktivitas siswa, terutama dalam berkolaborasi, berkomunikasi, berpikir kritis dan kreatif.
\end{abstract}

Kata Kunci: Lesson Study, TIK, Pembelajaran Bahasa, Microsoft Office

How to Cite: Primandhika, R. B., \& Firmansyah, D. (2018). The Quality Improvement in ICT Application For Indonesian Language Learning through Lesson Study for Learning Community. JEE, 1(1), 59-68. 


\section{INTRODUCTION}

The information and communication technology (ICT) gives a huge contribution towards education world, especially in the learning process. It gives the ease of communication and the effective way to manage information. As the learning process is now in the digital era, the learning society can access information either offline or online easily. Nevertheless, the technology is not only used for communication purpose but also can be utilised as learning media in the classroom, like video, audio, interactive software and others.

Remembering the fact, the mastery of ICT needs to be applied to the classroom learning. Both students and educators are expected to be skilful in using ICT-based devices, starting from software to hardware. Unfortunately, there is still an erroneous assumption from some educators in Indonesia regarding its importance. Only ICT teachers that are considered needing the proficiency in ICT application. In fact, all learning communities need to be proficient in supporting their own field of expertise. The use of ICT in the language-learning process has a significant impact on students, not only on their linguistic skill development but also in acquiring ICT-related skill through target language. (Chamber, Conacher, \& Littlemore, 2004, p. 10)

ICT learning is not only learned to know how to master the use of devices such as computers, its software, or smart-gadgets. In mathematical fields, for instance, ICT can be used for statistical application and 3D illustration for solids, shapes, etc. Not only that, ICT is interdisciplinary and can be applied in any field of expertise. One of them is language teaching and learning.

ICT learning in all level of education tends to be more practical than theoretical. In a lesson, to deliver the materials, the teacher demonstrates the procedure of using a software or how to use hardware or devices. After that, students repeat the instructions given by the teachers. Even though sometimes not all students are happy with that strategy of learning and the teacher does not know what to do, some strategies for learning can be used besides the demonstration, to improve the quality of learning. Accordingly, to provide solutions regarding this problem, lesson study is chosen.

Lesson study is a professional development practise in which teachers collaborate to develop a lesson plan, teach and observe the lesson to collect data on student learning, and use their observations to refine their lesson. It is a process that teachers engage in to learn more about effective practises that result in improved learning outcomes for students (Jennifer Stepanek, 2006, p. 4). The teachers, as a learning community, involved in three main phases, including planning, implementing, and evaluating.

Lesson Study for Learning Community aims at improving the quality of learning in ICT Application for Indonesian Language and forming the professional learning community among the teachers in IKIP Siliwangi. Therefore, through the lesson study, the learning is expected to be more collaborative, communicative, critical and creative both for the teachers and students.

\section{Lesson Study for Learning Community}

Japan is the first country to introduce lesson study as a learning method. The method was developed during the late 90s when the educators in Japan managed to solve learning quality problem faced by the teachers. At that time, Lesson study was practised for months until a 
suitable learning quality for delivering the materials to the students. Thus, these steps were obtained to be a reference for the educators.

as Stigler \& Hiebert in (Rock \& Wilson, 2005, p. 79) determined: (1) defining and researching a problem, (2) planning the lesson, (3) teaching and observing the lesson, (4) evaluating the lesson and reflecting on its effect, (5) revising the lesson, (6) teaching and observing the revised lesson, (7) evaluating and reflecting a second time, and (8) sharing the results. In lesson study, those steps are divided into three main phases consisting of:

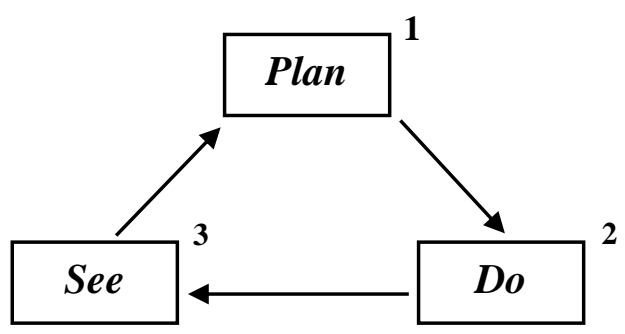

Figure 1. Lesson Study Cycle

\section{Lesson Plan}

The planning phase covers the discussion of the problems faced by the teachers in handling the class and planning the lesson that resulted in a lesson design that can be implemented by teachers for students.

\section{Implementation Stage (Do)}

After making lesson plans, teachers teach accordingly to the designed learning model. Meanwhile, the observer records students' activity during the learning process.

\section{Evaluation (See)}

The next step after learning is to review the findings during the lesson. Starting with the model teacher stating the difficulties as well as the success of the learning process, then followed by evaluation from observers about student activities. Thus, the model teacher will know what to improve for better learning in the next session.

\section{ICT Application in Indonesian Language Learning}

The use of ICT application in education, especially in language education, including Indonesian is a positive response towards the development of ICT and its ability to face global challenge. Therefore, the use of ICT application in education, especially in language education including Indonesian, is a positive response towards the development of ICT and its ability to face global challenge. The uses of ICT to support language learning is necessary, not only to improve the effectiveness and quality of learning but also for the provision of teachers and students to live in a technological era that is constantly changing and evolving. Language education is an area where open-access resources, online courses, virtual classrooms, and social networks based on information and communication technology (ICT) are being increasingly used to give learners access to information, promote interaction and communication, and enhance digital literacy skills. (Ernest \& Hopkins, 2013) 
Microsoft Office is a designation for office suite applications and designed to run under Windows operating system. Some of the well-known applications in Microsoft Office are Word, Excel, and PowerPoint (Noviandri \& Sarwandi, 2017, p. 1). Still, other software such as Publisher, OneNote, Access and Share-point has its own utility for their respective fields.

Before deploying the 2013 version of Microsoft Office, the software was preceded by the word "Microsoft." Along with its popularity, the word "Microsoft" is no longer used it for the software's full name. Simply by calling Word, for example, people know that the referenced is a word processing software issued by Microsoft. In this paper, the software will only be mentioned by its short name.

For editing and journalistic purposes, two of the software used are Word and OneNote. Word in Microsoft Office serves as a word processor that includes document editing and editing features. It is equipped with spell checkers in various languages and other advanced features. While OneNote is an online-based note-taking app that looks like a notebook with chapters and sections. The software is available on multiple platforms, such as Windows, Mac, iOS, or Android so it can be used anywhere and suitable for mobile journalistic purposes.

\section{RESEARCH METHODOLOGY}

Descriptive research was selected to find out the results of this study. ICT Application is chosen as a course in Indonesian language learning because it contains the application of technology for journalism and editing. It is the uniqueness of Indonesian Education Major in IKIP Siliwangi. This course has the potential to produce innovations for language learning. Thus, it is necessary to improve the quality of learning especially in finding suitable learning models or strategies.

This study involved 40 students of Indonesian Education Major, two model teachers and three other teachers as observers. The study lasted for two months from April to May 2017 in one of the classes in the major. The classes selected are classes that require an interactive learning strategy. It aims to make students more motivated and more active in presenting the findings related to learning materials. With a lesson-based study, ICT Applications in Indonesian Language Learning found several findings ranging from learning problems to a suitable learning model to solve the problem.

\section{RESULTS AND DISCUSSION}

The research focused on three phases of lesson study to measure the development of the improvement. The phases are lesson planning, implementation stage ( $d o$ ) and evaluation (see). Students' activity will be observed, and the teacher's findings will be expressed during two cycles containing five meetings. The result of each meeting will be discussed in accordance with what was revealed in evaluation session.

\section{Cycle I Meeting 1}

The first meeting begins with a planning session where the model teachers convey what things to be delivered in the classroom. The delivered material is about the use of OneNote. Model teachers and observers try to explain some of the functions that excel at the Microsoft OneNote registry program. The observers provide some input that would be necessary for the learning at the time. 


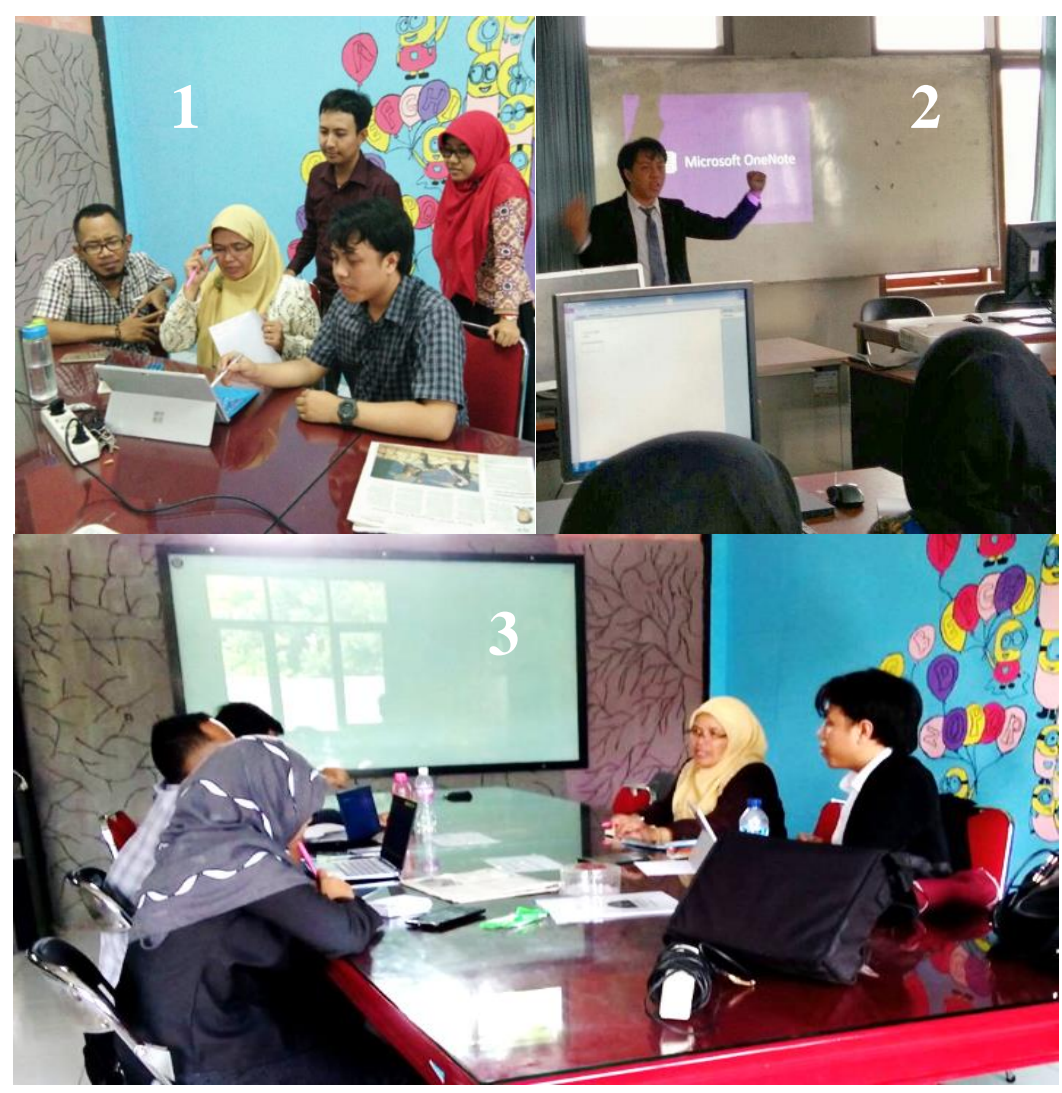

Figure 2. The sequence of lesson study containing of $\mathrm{plan}^{1}, d o^{2}$ and $s e e^{3}$

In the implementation stage (do), learning takes place in line with the plan. The material given in this session consists of $30 \%$ of the material on skills theory and $70 \%$ of instructional practise. These include the arts of taking notes and instructions for the use of digital notes, ranging from 1) creating a tick box 2) mind-mapping. The two mentioned are new to the students because previously, students took notes using Word.

At the time of the practise, the students were still unfamiliar with the interface of the software and still adjusting to the toolbar. They tend to do the instruction in groups, but it is better for the program to be tried on individuals. Students are more comfortable to ask their peers than directly to the instructor. The results indicate that there is a need for improvement: 1) facilitating students to actively participate in learning 2) ensuring students follow the material 3) technical improvement for the computer laboratory 4) reviewing the lesson by giving the students a chance to practise what has been taught.

\section{Cycle I Meeting II}

This meeting begins with a planning session where model teachers and observers revise the format of learning activities based on the four findings at the first meeting. By giving the students the opportunity to express their opinions and work collaboratively, learning is expected to bring the four aspects to the students: 1) collaborating skills 2) communication skills 3) critical thinking skills 4) creative thinking skills. 


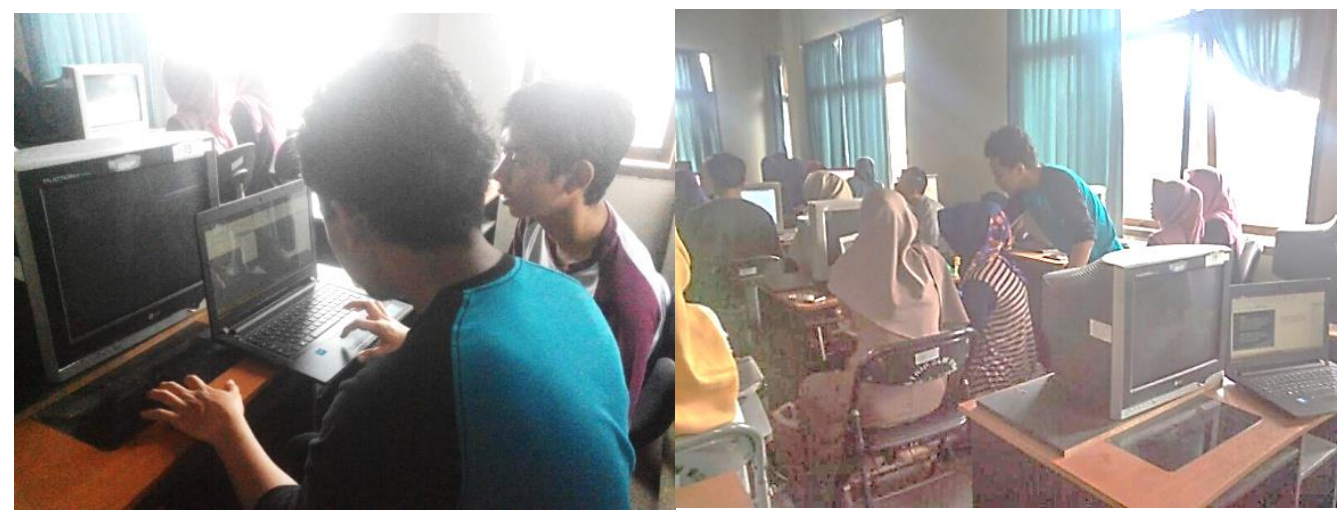

Figure 3. Collaborative acts between one students and another

In this do session, there are collaborations between students when practising the material. Students can collaborate with their peers, where one instructs, and one demonstrates. This indicates that the student is getting used to the toolbar on OneNote. Unfortunately, not all of the aspects above can be applied in the meeting because the material is still largely dominated by the form of instruction. Thus, some students do activities outside the practise as shown in the following figure:

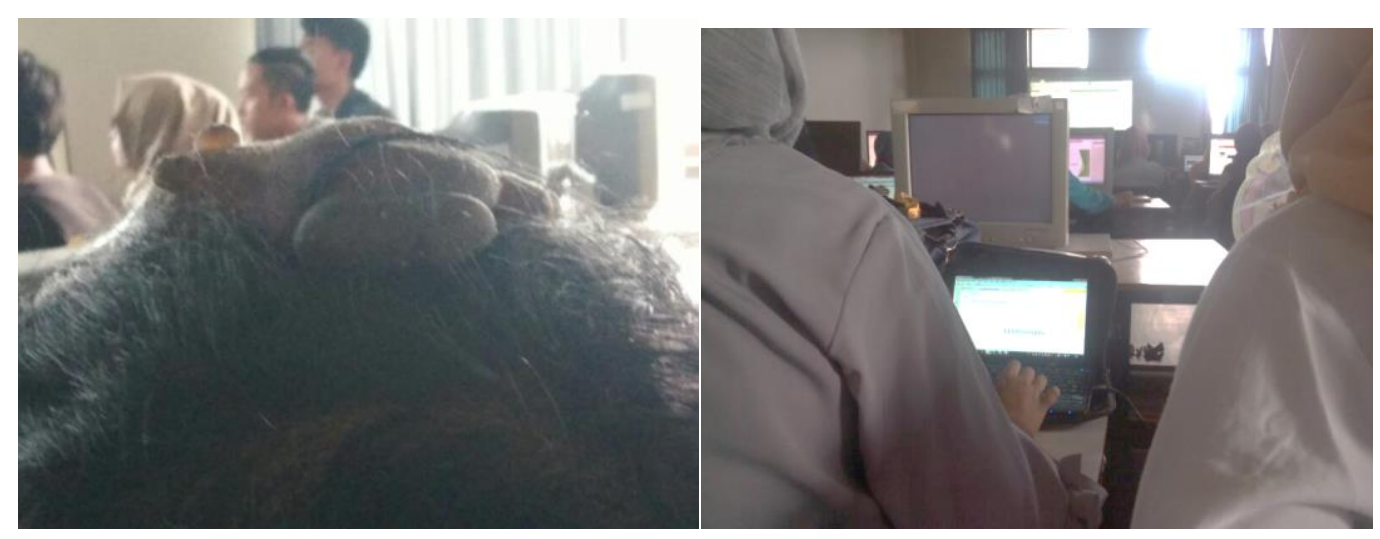

Figure 4. Students' problems: playing with rubber toy and typing random text during the practise

\section{Cycle II Meeting I}

Referring to the findings of previous meetings, it appears that some lecture materials need to be fixed so it can make students more focused. In this cycle lesson plan, the model teachers and the observers seek a solution for the problematic learning strategy. Then the learning strategy was altered along with the changing material. The basics of using Word software will be delivered through problem-based learning. Each student is given a topic where they have to use software features (such as Drop Cap, Text Wrapping and Paragraph Formatting) and later remodelled it with the group. 
In the practise, this strategy is quite successful for controlling the classroom in order to create a collaborative learning environment. This is shown by the need of the students to solve a problem given by the instructor. So almost all groups found by observer look focused, as shown in the following figure:

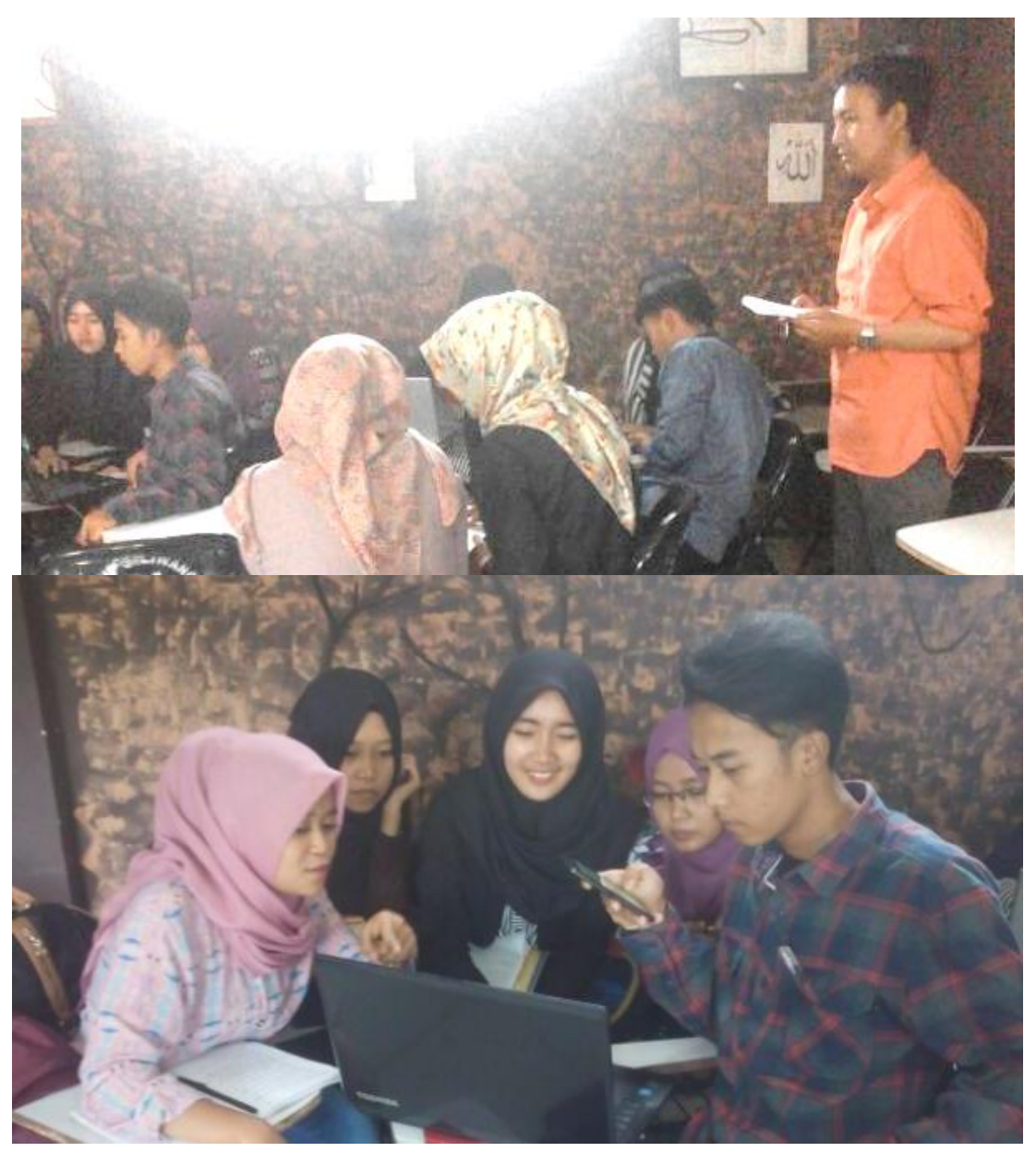

Figure 5. Observer found students' collaboration.

In the evaluation sessions, some things still need to be fixed. For some students, the given instruction is too general. As a solution, model teachers help to solve some practical problems so that the students can continue learning.

\section{Cycle II Meeting II}

For the successful implementation of learning in the earlier session, a team consisting of model teachers and observers decided to keep using the strategy. After developing collaboration and communication skills, the critical and creative thinking skills are expected to be at the next meeting. 
This time, the same method will be used to discuss next material about page separation and table of contents in Word. But at this point, students are given more opportunity to express their opinions in order to achieve the expected aspects.

At the start, the students felt that the topic for the meeting was complicated because the teachers gave instructions on how to apply the current material to their own proposals. However, after being given the opportunity to express their findings, a group may appear to be an "enlightenment" for other groups:

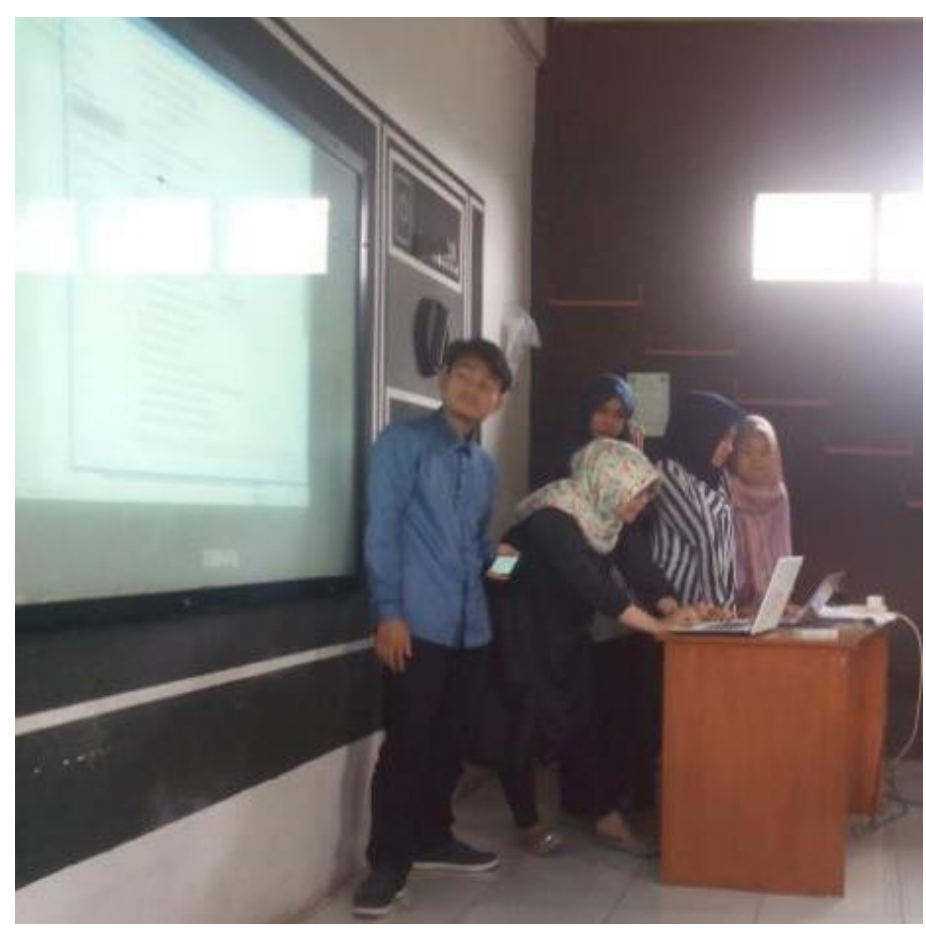

Figure 6. A group presented their findings of the topic "section break and automatic reference" in Word

At the evaluation session (see) it was found that the students were more interested in the explanation done by their peers as the instructors. In addition, the group can also discover new things such as shortcuts and things related to the page separation.

The teams also need to consider designing more student-centred learning method. It proves that the method had encouraged more critical thinking in solving problems as well as creative thinking skills. Piaget (Suparno, 1997) holds that the acquisition of knowledge should be obtained by action and active interaction from students towards the environment.

\section{Cycle II Meeting III}

The material presented in this cycle is about advanced features in Word used for customising the scientific article templates. In the session plan, the team discussed to add input to lesson design made by the model teacher so that the students pay more attention to writing rules such as typography and journal template considering the distinctive styles. 
Students continued learning in groups. First, the teacher explained the Scientific Article and the style used. Each student tried to convert their proposals to the form of journals. This assignment became a challenge for the students because the rules and writing style is different from the ones they normally used in their daily assignments. To help the students understanding the material, the model teacher reminded about the Word features given in the previous session.

After doing treatment considering the material, the student groups were then directed to follow the template and author guidelines in one of the journals. After that, the teacher asked the groups to show several Microsoft Office features used to customise the writing according to the style of the current scientific journal. It helped the groups to get some ideas that improve their understanding of the writing style of scientific articles.

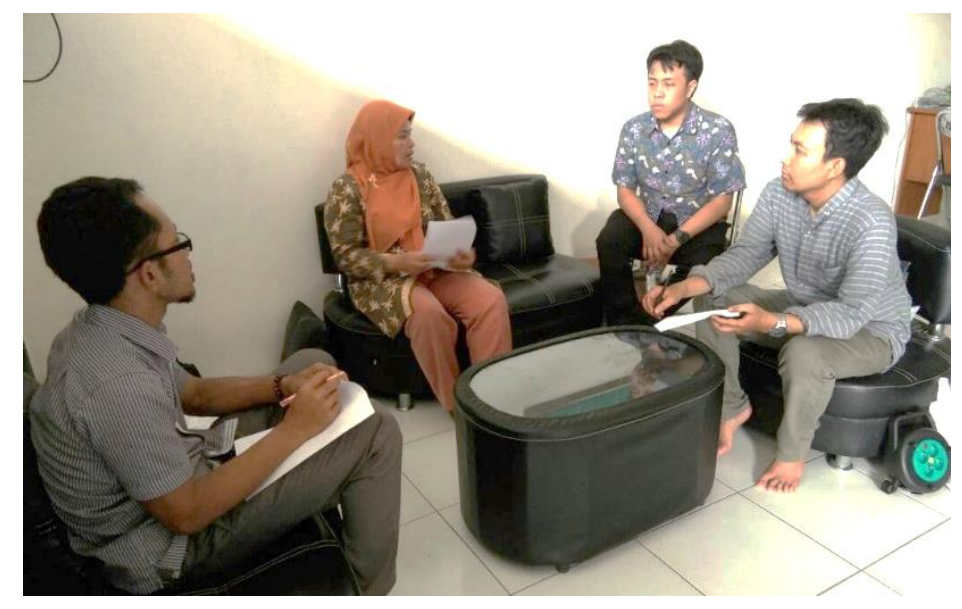

Figure 6. Lesson study team in last evaluation session

In the evaluation session, the students began to understand the style of writing different scientific papers for different purposes or publishing, especially the one published globally in the electronic media. It has the strict guidance of writing style of the electronic scientific papers that published periodically. It will also be a student requirement for the final assignment.

Having taken several meetings, the teams and students found that the use of ICT Applications is not applied in technology alone. This course is also important in the world of education, language, journalism, and editing.

\section{CONCLUSION}

Based on the result and discussion of lesson study for the learning community, it can be concluded that:

1. There is an improvement in the lesson of ICT Application for the Indonesian Language shown by the improvement of students' ability in collaboration skills, communication skills, critical thinking, and creative thinking.

2. There is an improvement of the teachers' quality shown by the teachers' comprehension towards the lesson and creativity. Besides, the learning community among the teachers is also formed to create innovative teaching methods.

Based on the results of the activities and the conclusion, the author recommends:

1. Lesson Study for Learning Community activities can be conducted regularly and periodically in courses that need improving the quality of learning. 
68 Primandhika, R. B., \& Firmansyah, D. (2018). The Quality Improvement in ICT Application For Indonesian Language Learning through Lesson Study for Learning Community. JEE, 1(1), 59-68.

2. Lesson Study for Learning Community activities can also be applied in community service activities at IKIP Siliwangi by collaborating with school teachers in remote areas of West Java.

\section{ACKNOWLEDGMENTS}

Upon the completion of this research, the authors would like to say gratitude to Allah s.w.t. for his mercy and grace. We also thank the Vice Rector I of IKIP Siliwangi, Ibu Dr. Hj. Euis Eti Rohaeti, M. Pd. for facilitating the authors to continue to develop our potential especially in the field of education. As well as the head of the study program, Dr. Hj. Wikanengsih, M. Pd. for his guidance during the lesson study, also the observers Bapak Yusep Ahmadi, M. Hum, Ibu Yeni Rostikawati, M. Pd., students of IKIP Siliwangi Class A1 class of education 2014 as well as all parties involved in this research.

\section{REFERENCES}

Chamber, A., Conacher, J. E., \& Littlemore, J. (2004). ICT and Language Learning. (J. E. A Chambers, Ed.) London: A\&C Black.

Ernest, P., \& Hopkins, J. (2013, Januari). Use of ICT in support of language teaching and learning. Retrieved from ECML: https://www.ecml.at/TrainingConsultancy/ICTREV/tabid/1725/language/en-GB/Default.aspx

Jennifer Stepanek, G. A. (2006). Leading Lesson Study: A Practical Guide for Teachers and Facilitators. California: Corwin Press.

Noviandri, H., \& Sarwandi. (2017). Microsoft Office 2016 untuk Pemula. Jakarta: Elex Media Komputindo.

Rock, T. C., \& Wilson, C. (2005). Improving Teaching through Lesson Study. Teacher Education Quarterly, 77-92.

Suparno, P. (1997). Filsafat Konstruktivisme dalam Pendidikan. Kanisius: Yogyakarta. 